\title{
UZBEKISTAN - THE ALLEGED NATIVE RANGE OF THE INVASIVE ANT LASIUS NEGLECTUS (HYMENOPTERA, FORMICIDAE): GEOGRAPHICAL, ECOLOGICAL AND BIOLOGICAL EVIDENCES
}

\author{
S. V. Stukalyuk ${ }^{1}$, A. G. Radchenko ${ }^{2}$, A. Akhmedov ${ }^{3}$, A. A. Reshetov ${ }^{4}$ \\ ${ }^{1}$ Institute for Evolutionary Ecology of the NAS of Ukraine, Acad. Lebedeva st., 37, Kyiv, 03143 Ukraine \\ E-mail:asmoondey@gmail.com \\ ${ }^{2}$ Schmalhausen Institute of Zoology NAS of Ukraine, vul. B. Khmelnitskogo, 15, Kyiv, 01030 Ukraine \\ E-mail: rad@izan.kiev.ua \\ ${ }^{3}$ Institute of Zoology of the Academy of Sciences of the Republic of Uzbekistan, Bogishamol st., 232, Tashkent, \\ 100053 Uzbekistan \\ ${ }^{4}$ Rostov Research Institute of Microbiology and Parasitology, Gazetniy lane, 119, Rostov-on-Don, 344000 Rus- \\ sian Federation \\ ${ }^{*}$ Corresponding author \\ S. V. Stukalyuk (http://orcid.org/0000-0002-9775-0750) \\ A. G. Radchenko (https://orcid.org/0000-0002-8850-0530) \\ A. Akhmedov (http://orcid.org/0000-0002-1864-5670) A. \\ A. Reshetov (http://orcid.org/0000-0003-3525-0731)
}

\begin{abstract}
Uzbekistan - the Alleged Native Range of the Invasive Ant Lasius neglectus (Hymenoptera, Formicidae): Geographical, Ecological and Biological Evidences. Stukalyuk, S. V., Radchenko, A. G., Akhmedov, A., Reshetov, A. A. - Invasive ant species Lasius neglectus is widespread from Canary Islands to Central Asia, inhabiting almost exclusively anthropogenic habitats (cities, towns, villages), but its native area has remained unknown untill now. We recently found numerous populations of this species in Uzbekistan, where it lives in the natural habitats throughout the country except for arid zones - the Kyzylkum desert and the Ustyurt plateau. Lasius neglectus inhabits here mesophytic, moderately humidified biotopes at the altitudes from 91 to $1982 \mathrm{~m}$ a. s. 1., but is also common in urban areas. Colonies of L. neglectus in the natural habitats are polygynous, but monocalic, it has the true nuptial flight, its workers are aggressive toward conspecific workers from other nests. Based on obtained data we assumed that the native range of L. neglectus is Central Asia (particularly, Uzbekistan).

Ke y words: Lasius neglectus, invasive species, Uzbekistan, native range, colony structure, nuptial flight, aggressiveness.
\end{abstract}




\section{Introduction}

The study of the biology of invasive ant species is one of the promising areas of modern myrmecology. Of nearly 13.7 thousand currently described species of ants more than 200 of them were introduced into the regions where they were absent, and some of them became invasive, spreading to vast territories (Suarez et al., 2010). Spreading of invasive species in most cases occur due to human activity in the transportation of goods, tree seedlings, soil, etc.

Many invasive ant species share a number of common biological features: supercoloniality or even unicoloniality, when some populations form continuous colonies extending tens or even hundreds of kilometers; a high polygyny; often fertilization of queens inside the nest without nuptial flight; as a rule, also tolerance towards workers from other nests and aggressiveness towards workers of other ant species (Holway et al., 2002; Giraud et al., 2002; Tsutsui \& Suarez, 2003; Wetterer \& Wetterer, 2006; Wetterer, 2008; Ugelvig et al., 2008; Radchenko \& Elmes, 2010). All this gives invasive ants a competitive advantage over native species.

One of the invasive species is Lasius neglectus Van Loon, Boomsma et Andrásfalvy, 1990. In Europe, it was first discovered in 1973 in Budapest, but was described only in 1990. Its known range extends from the Canary Islands through Central and part of Southern Europe, Asia Minor and the Caucasus to Iran and Israel, and there is an isolated part of the range in Kyrgyzstan, Uzbekistan and Tajikistan (Seifert, 2000; Schultz \& Seifert, 2005; Schultz et al., 2006; Espadaler et al., 2007; Czechowski et al. 2012; Radchenko et al., 2012; Radchenko, 2016; Stukalyuk, 2017; Buckham-Bonnett \& Robinson, 2018; Stukalyuk \& Radchenko, 2018; our data in this article). That is L. neglectus may be considered the most widespread invasive species of ants in the western and central Palaearctic (except for Monomorium pharaonis (Linnaeus, 1758), which inhabits in the temperate zone exclusively premises, heated during the cold seasons).

For a number of invasive species the native (or primary) range is known. For example, the widespread in the Mediterranean Linepithema humile (Mayr, 1868) comes from a relatively small region in the Parana river basin in South America (Wild, 2004); the native range of Crematogaster subdentata Mayr, 1877 that was introduced to the south of Eastern Europe, is Central Asia (Mayr, 1877; Stukalyuk, 2015; Radchenko, 2016); the Palaearctic Myrmica rubra (Linnaeus, 1758) has become a dangerous invasive species in North America (Radchenko \& Elmes, 2010; Wetterer \& Radchenko, 2011; Chen \& Adams, 2018).

The place of origin of $L$. neglectus has so far remained unknown. Since it is morphologically resembles Minor Asian L. turcicus Santschi, 1921, it was assumed that L. neglectus could arise in Asia Minor and subsequently spread widely both to the west and to the east (Seifert, 2000; Cremer et al., 2008; Ugelvig et al., 2008; Stukalyuk \& Radchenko, 2018), but these assumptions have not been confirmed by real zoogeographic or biological evidence. Anyway, all researchers consider known to date range of this species as a secondary one, where L. neglectus inhabits almost exclusively anthropogenic landscapes - city parks, gardens, etc. Herewith it possesses the biological characteristics of invasive species listed above: a high level of polygyny and polycaly, formation of supercolonies, absence of nuptial flight and fertilization of queens inside nests, tolerance towards workers of their own species from neighboring nests and aggressiveness towards other species, and a negative impact on the indigenous ant species in many cases (Seifert, 2000; Rey \& Espadaler, 2004; Espadaler et al., 2007; Tartally et al., 2016; Stukalyuk \& Radchenko, 2018).

At the same time, the biological features of many invasive species in the native range are significantly different from those in the secondary one. They often characterized here by intraspecific aggressiveness (Wetterer, 2008), absence or extreme rarity of polycalic colonies (Radchenko \& Elmes, 2010), and have nuptial flight.

One of the authors of this article (AA) discovered in 2018-2019 numerous populations of L. neglectus in Uzbekistan. We present below the results of our studies of the distribution and biotopic preferences of this species in Uzbekistan and partially in Tajikistan, the biological features of this species in natural and anthropogenic habitats. The aim of our work was to find out the differences in colonies structure and behavior of Lasius neglectus from the Central Asian (Uzbekistan) and European (Rostovon-Don) populations. In particular, to determine the average number of queens in colony, the policaly or monocaly of colonies, aggressiveness or loyalty of workers to their own and other species of ants, as well as the presence or absence of nuptial flight.

Based on the analysis of the obtained results, we presume that the native range of L. neglectus lies in the Central Asia.

\section{Material and methods}

Our studies were conducted in 2018-2019 in Uzbekistan (20 places), Tajikistan (one place) (table 1, fig. 1) and the Russian Federation (Rostov-on-Don). In total, 665 workers of L. neglectus were collected, as well as about 20 gynes and males. Route counting of the nests was also carried out along the strips of $10 \mathrm{~m}$ width, where entrance to the nests of $L$. neglectus were usually found under stones and tree trunks and moving of this species workers was observed.

Based on the obtained data we made conclusion about the distribution of L. neglectus in primary habitat. 
Table 1. Collection sites of Lasius neglectus in Uzbekistan and Tajikistan

\begin{tabular}{|c|c|c|c|c|c|}
\hline \multirow[b]{2}{*}{ No } & \multirow[b]{2}{*}{ Collection sites } & \multicolumn{2}{|c|}{ Coordinates } & \multirow{2}{*}{$\begin{array}{l}\text { Altitude } \\
\text { (a.s.l.), m }\end{array}$} & \multirow{2}{*}{$\begin{array}{c}\text { Number } \\
\text { of collected } \\
\text { nests }\end{array}$} \\
\hline & & $\begin{array}{l}\text { northern } \\
\text { latitude }\end{array}$ & $\begin{array}{c}\text { eastern } \\
\text { longitude }\end{array}$ & & \\
\hline 1 & Tashkent, streets and courtyards & $41^{\circ} 17^{\prime} 7.34^{\prime \prime}$ & $69^{\circ} 15^{\prime} 46.43^{\prime \prime}$ & 430 & 15 \\
\hline 2 & Parkent, Tashkent region & $41^{\circ} 14^{\prime} 24.74^{\prime \prime}$ & $69^{\circ} 33^{\prime} 53.47^{\prime \prime}$ & 531 & 5 \\
\hline $3^{*}$ & Aksag-Ata natural boundary & $41^{\circ} 21^{\prime} 26.23^{\prime \prime}$ & $69^{\circ} 56^{\prime} 33.22^{\prime \prime}$ & 1414 & 9 \\
\hline 4 & Tashkent, botanical garden & $41^{\circ} 20^{\prime} 40.08^{\prime \prime}$ & $69^{\circ} 18^{\prime} 59.54^{\prime \prime}$ & 475 & 9 \\
\hline $5^{\star}$ & Hodjikent & $41^{\circ} 36^{\prime} 35.63^{\prime \prime}$ & $69^{\circ} 54^{\prime} 39.82^{\prime \prime}$ & 830 & 12 \\
\hline $6^{*}$ & Neighborhood Pistal Tau & $40^{\circ} 18^{\prime} 32.80^{\prime \prime}$ & $67^{\circ} 19^{\prime} 46.99^{\prime \prime}$ & 1019 & 17 \\
\hline $7^{\star}$ & Spurs of the Nurata Range & $40^{\circ} 19^{\prime} 21.06^{\prime \prime}$ & $67^{\circ} 16^{\prime} 45.99^{\prime \prime}$ & 959 & 21 \\
\hline 8 & Ferghana & $40^{\circ} 22^{\prime} 54.05^{\prime \prime}$ & $71^{\circ} 47^{\prime} 12.44^{\prime \prime}$ & 585 & 7 \\
\hline 9 & Kokand & $40^{\circ} 31^{\prime} 49.09^{\prime \prime}$ & $70^{\circ} 56^{\prime} 20.18^{\prime \prime}$ & 416 & 4 \\
\hline 10 & Namangan & $41^{\circ} 00^{\prime} 50.87^{\prime \prime}$ & $71^{\circ} 39^{\prime} 55.55^{\prime \prime}$ & 447 & 3 \\
\hline 11 & Jizzak & $40^{\circ} 7^{\prime} 35.95^{\prime \prime}$ & $67^{\circ} 50^{\prime} 18.74^{\prime \prime}$ & 371 & 16 \\
\hline 12 & Samarkand & $39^{\circ} 37^{\prime} 29.15^{\prime \prime}$ & $66^{\circ} 57^{\prime} 15.94^{\prime \prime}$ & 742 & 21 \\
\hline $13^{*}$ & Gissar Reserve & $38^{\circ} 57^{\prime} 11.98^{\prime \prime}$ & $67^{\circ} 20^{\prime} 5.46^{\prime \prime}$ & 1982 & 25 \\
\hline 14 & Karshi & $38^{\circ} 52^{\prime} 47.58^{\prime \prime}$ & $65^{\circ} 47^{\prime} 53.86^{\prime \prime}$ & 378 & 5 \\
\hline 15 & Termez & $37^{\circ} 13^{\prime} 5.29^{\prime \prime}$ & $67^{\circ} 17^{\prime} 1.58^{\prime \prime}$ & 300 & 7 \\
\hline $16^{*}$ & Badai-Tugay Nature Reserve & $41^{\circ} 59^{\prime} 39.70^{\prime \prime}$ & $60^{\circ} 21^{\prime} 44.06^{\prime \prime}$ & 91 & 30 \\
\hline 17 & Bukhara & $39^{\circ} 45^{\prime} 29.34^{\prime \prime}$ & $64^{\circ} 25^{\prime} 25.77^{\prime \prime}$ & 227 & 9 \\
\hline 18 & Khiva & $41^{\circ} 22^{\prime} 55.90^{\prime \prime}$ & $60^{\circ} 22^{\prime} 04.21^{\prime \prime}$ & 97 & 11 \\
\hline 19 & Urgench & $41^{\circ} 32^{\prime} 53.34^{\prime \prime}$ & $60^{\circ} 37^{\prime} 52.53^{\prime \prime}$ & 102 & 11 \\
\hline 20 & Nukus & $42^{\circ} 27^{\prime} 35.68^{\prime \prime}$ & $59^{\circ} 36^{\prime} 4.89^{\prime \prime}$ & 76 & 15 \\
\hline 21 & Tajikistan, Varzob (Mountain Botanical Station) & $38^{\circ} 48^{\prime} 36.20^{\prime \prime}$ & $68^{\circ} 49^{\prime} 11.90^{\prime \prime}$ & 1250 & 7 \\
\hline
\end{tabular}

*Natural habitats.

To determine the number of queens per colony and the relationship between the nests of L. neglectus, six nests were excavated in Uzbekistan (sites 1-5, 7), and five nests - in Rostov-on-Don. Excavations were carried out according to Espadaler et al. (2004). Excavations were carried out between neighboring nests, as well as in the adjacent territory around nest entrances to a depth of $1 \mathrm{~m}$ in the form of trenches. As a result, it was found that in the natural population all nests of L. neglectus were monocalic and do not have any connections by tunnels. On the contrary, the nests in Rostov-on-Don were polycalic and connected by tunnels. After establishing the presence of tunnels between the nests, we determined the boundaries of the supercolony along its perimeter, e. g. by the trunks of the extreme trees on which where workers L. neglectus foraged. However, such supercolonies (or primary federations) in Rostov are territorially separated from each other by the distances of several tens of even hundreds of meters, since they are tied to separate groups of trees (forest belts, parks), and, as a rule, the supercolonies of another invasive species, $C$. subdentata, are located between them or by xerophytic vegetation, where both species are absent. At the same time, no connections by tunnels between neighboring supercolonies of L. neglectus were found, and this was the basis for conducting aggressive tests between them.

Intraspecific aggression tests between workers of $L$. neglectus from different colonies were conducted according to LeMoli \& Parmigiani (1981). The workers for experiments were collected a 1 day before providing tests on the foraging territories, very close to the nests' entrances. To exclude the possibility of getting into the group of the experiment on the aggression the intranesting workers, all workers were collected only from the foraging trails or on tree trunks at a length of $1 \mathrm{~m}$ from the nest entrances. All workers from different nets in the intraspecific tests were marked by different colors.

The experimental nests of L. neglectus in the native area (Tashkent, botanical garden) were located at the distances from 20 to $100 \mathrm{~m}$ of each other, and those in the secondary area (the forest belt in the suburbs of Rostov-on-Don) were on the territory of the supercolony of this species. The experimental nests in the in- 
terspecific aggression tests between $L$. neglectus and C. subdentata were located in the same site as above near Rostov-on-Don at the distances from 10 to $15 \mathrm{~m}$ of each other. All tests were carried out at the air temperature $23-25{ }^{\circ} \mathrm{C}$ and the relative humidity $70-80 \%$, what corresponds to these parameters in the natural habitats in June. Workers for aggressiveness were kept for one day before tests in laboratory in the Petri dishes with a thin layer of sand at the bottom. Each group of workers was held in a separate container. Five hours before the start of the experiment the ants were fed with honey syrup.

15 tests were carried out in Uzbekistan: five tests in each of the following categories: one on one, five on five and 10 on 10 workers from three different nests, accounting time was 2 minutes (Stukalyuk \& Netsvetov, 2018). In total, 75 ants were collected from each of the three nests (5 workers in the experiments 1 to 1,25 in 5 to 5 and 50 in 10 to 10 ).

To compare intraspecific and interspecific aggression, we conducted similar nine tests with the same ratio of workers with another local dominant species C. subdentata (by $3+15+30$ workers of L. neglectus and C. subdentata from three nests of each species). Three tests were performed in each category. Similar tests we conducted in Rostov-on-Don: five tests one on one, and three each test five on five and 10 on 10 workers of L. neglectus (5+15+30 workers of $L$. neglectus from each three nests), and three tests for each one on one, five on five and 10 on 10 workers of L. neglectus vs. C. subdentata (by $3+15+30$ workers of both species from three nests of each). The ants were placed in fighting boxes using the thin brush, on which they climbed on. Each of the groups was separated by a partition, which was removed before the start of experiment. To exclude the deviant behavior of the ants after the transfer, the exposure before removing the septum was 30 minutes. Moreover, to exclude deviant behavior the same workers did not participate in the different tests. All tests were recorded on video; the videos were processed to determine the average number of behavioral reactions in ants. In some cases frame-by-frame video processing was performed.

The following behavioral reactions were taken into account during testing: 1 - swoops and bounces; 2 opening of the mandibles; 3 - attack the enemy's appendages (legs, antennae) with mandibles, 4 - attack the head and waist with mandibles; 5 - attack on the head or appendages with mandibles using poisonous secrets; 6 - the average number of ants killed per one test; 7 - peaceful contacts (mutual contacts with antennae, licking); 8 - pose of threat.

Statistical analysis of the data was performed using the program Past v. 3.0, the differences between the sings are significant at $\mathrm{p} \leq 0.05$. To compare the data from different samples, we used the Fisher t-test (with a normal distribution of the trait) for independent samples. Pearson correlations were calculated for behavioral reactions in the aggressiveness tests. Correlations between behavioral responses were determined to establish aggressiveness or tolerance. Thus, active antennae contact corresponds to loyal behavior and disclosure of mandibles, a threatening pose or the use of poisonous secrets correspond to aggressive behavior. Thus, it is possible to determine what behavior prevails between workers from different, spatially unconnected nests - aggressiveness or loyalty.

\section{Results}

Distribution of L. neglectus in the natural habitats of Uzbekistan

L. neglectus is widespread everywhere outside the settlements of Uzbekistan, with the exception of arid zones - the Kyzylkum desert and the Ustyurt plateau. Here it was found in a variety of mesophytic, moderately humidified habitats, most often in cereal grasslands (table 1). It was found in the mountains, where it is common in tree-shrubbery thickets, along river banks, near springs and in the valleys of small rivers that dry up in summer. It is also very abundant in cities, since cities' environments are similar with mesophytic natural habitats.

On average, L. neglectus lives in Uzbekistan at altitude of about $600 \mathrm{~m}$ a. s. 1., but in a very wide range - from 91 to $1982 \mathrm{~m}$. It nests most often in soil under stones, as well as at the tree bases. L. neglectus often coexists with the species of the subgenus Serviformica Forel, 1913 of the genus Formica Linnaeus, 1758, which also prefer moistened habitats. Moreover, they often forage on the same tree and can even build nests under same stone.

\section{Alleged native range of L. neglectus}

The region of Uzbekistan encircled by black line in the figure 1, is mesophytic, quite humid and covers high mountain ranges and their spurs, large and well-greened cities, floodplains and river basins (especially the two largest ones, Amu Darya and Syr Darya), agricultural landscapes (fields, gardens). It is this region is favorable for dwelling of 


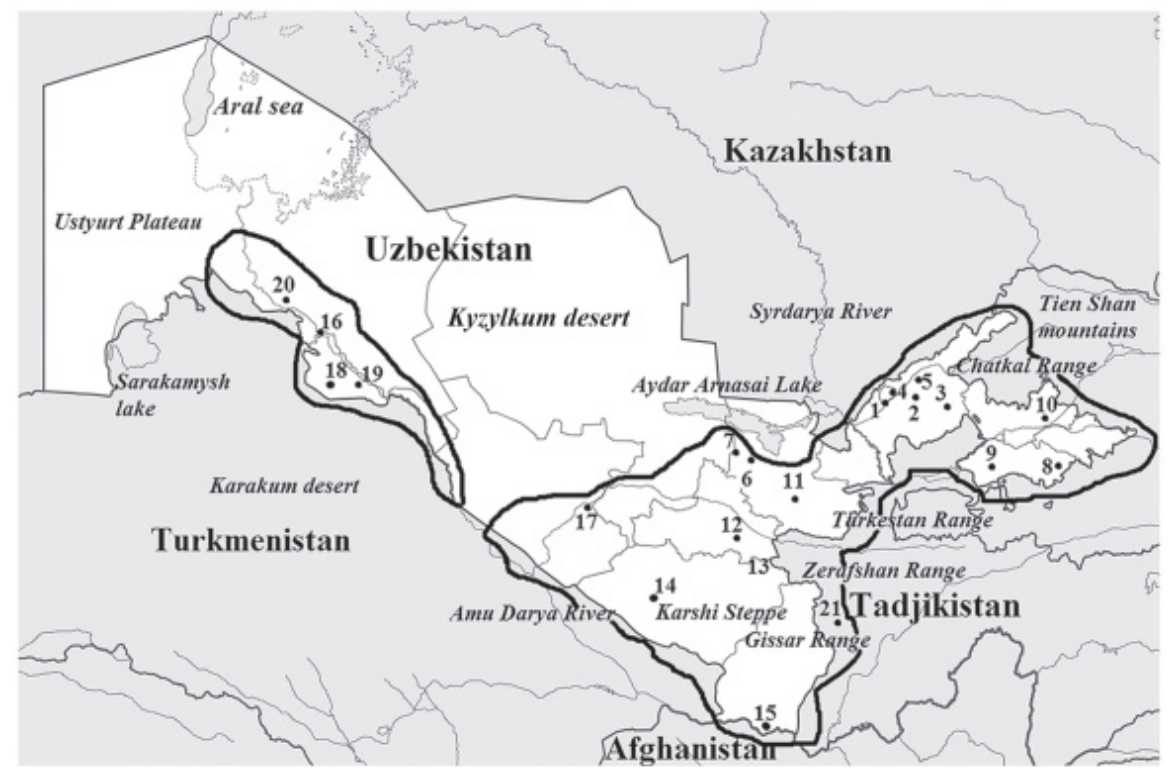

Fig. 1. Collection sites of Lasius neglectus in Uzbekistan (1-20) and Tajikistan (21). Note: numbering of collection sites as in table 1; the bold line encircles the assumed native range of L. neglectus.

L. neglectus, what is confirmed by our investigations. The rest of the territory of Uzbekistan (Ustyurt plateau, Kyzylkum desert) is too dry, and L. neglectus was not found here not only in the natural habitats, but even in the large cities - Uchkuduk and Zarafshan. Except for Kyrgyzstan (Schultz \& Seifert, 2005), data on the distribution of L. neglectus in neighboring mountain regions are still insufficient, but its discovery in Tajikistan may indicate a wider distribution of L. neglectus in that country, and possibly also in Afghanistan.

\section{Polygyny of L. neglectus and nuptial flights}

On average, there are $8.5 \pm 1.7$ queens per colony of $L$. neglectus in Uzbekistan, but the average number of queens in Tashkent and other cities was $13.2 \pm 3.3$ (minimum - six, maximum - 25), which is 2.3 times more $(\mathrm{p} \leq 0.05)$ than these in the natural habitats $(5.6 \pm$ 0.9 queens on average, minimum - three, maximum - nine). We did not find monogynous colonies neither in the natural, nor in the urban habitats. The distance between nests of L. neglectus in natural habitats was at least $10 \mathrm{~m}$, and no tunnels connecting neighboring nests were found during the excavation of the nests. This may suggest that in the natural habitats in the native range of $L$. neglectus its colonies are polygynous, but monocalic.

At the same time, the average number of queens in small colonies of L. neglectus in various parts of its secondary range is comparable to that in the natural habitats of Uzbekistan: $5.8 \pm 0.8$, but in large polycalic colonies there are much more queens - from 20 to hundreds and thousands (Espadaler et al., 2004), i. e., all L. neglectus colonies in the native range contain much less queens compared to supercolonies in the zone of invasion.

One of the important biological feature of $L$. neglectus in the native range compared to the secondary one is the presence of a true nuptial flight, which usually occurs from midMay to early June, but in different years this period may somewhat vary. Males and gynes massively leave their nests before nuptial flight, blast off and form swarms. There are always more males in a swarm than gynes, and in some cases only males emerge from nests (for example, in Hojikent 25.05.2018 there were only males, 03.06.2018 in Badai-Tugay Nature Reserve and 30.05.2018 in spurs of the Nurata Range - gynes and males; 06.06.2018 — in the Tashkent Botanical Garden, gynes and males); males also fly to the light during the dark. The flight usually occurs at sunset, when the air temperature drops, but in cooler weather it can 
happen earlier during the day. Mating starts in the air, and then copulating pairs land to the ground. Fertilized gynes run on various substrates searching for places for founding a new nest most often after sunset. Most probably, fertilized gynes of L. neglectus, like other species of the subgenus Lasius s. str., are able to independently establish a new colony.

\section{Interspecific and intraspecific aggressiveness}

The aggressiveness of $L$. neglectus differs (based on the average number of reactions per test) in the native and secondary ranges depending on the number of individual and species of ants involved in conflicts (table 2).

For example, killed ants in intraspecific conflicts in L. neglectus in the native area (Tashkent, Botanical Garden) appeared only in 10 to 10 workers tests. At the same time, the number of $L$. neglectus workers killed in interspecific conflicts with another local dominant C. subdentata, was three times lower in 10 to 10 tests, compared to the number of $L$. neglectus workers killed in intraspecific tests $(\mathrm{p} \leq 0.05)$. This indicates a lower level of interspecific tension in L. neglectus compared to intraspecific one in the native range. L. neglectus in case of conflicts with C. subdentata in most cases behaved as a subordinate species, avoiding direct contacts or taking a pose of submission. If workers of L. neglectus attacked first C. subdentata, they were immediately killed, but usually (in $90 \%$ cases) workers of $C$. subdentata attack workers of $L$. neglectus first. With an increasing of the quantity of participants in conflicts, the number of attacks and threatening poses (opening of mandibles) also increased.

\section{Correlations}

The following correlations were recorded in intraspecific tests of aggressiveness of L. neglectus in the native area (Tashkent, Botanical Garden). In the one to one test, the correlation between opening of the mandibles and the swoops was $0.91(p \leq 0.02)$. Three correlations were recorded in the tests five to five: between swoops and attack appendages by mandibles $(0.72, \mathrm{p} \leq 0.05)$, between swoops and attack using mandibles $(0.72, \mathrm{p} \leq 0.05)$, as well as between swoops and antennal contacts $(0.72, \mathrm{p} \leq 0.05)$. In the tests of 10 to 10 workers, correlations were obtained between swoops and opening of the mandibles $(0.68, \mathrm{p} \leq 0.05)$, swoops and attacking appendages with the mandibles $(0.72, \mathrm{p} \leq 0.05)$, attacking appendages by mandibles and opening of mandibles $(-0.79, \mathrm{p} \leq 0.05)$, swoops and attacking the head and waist using mandibles $(0.58, \mathrm{p} \leq 0.05)$, opening of the mandibles and attacking the head and waist by mandibles $(-0.90, \mathrm{p} \leq 0.05)$, attacking the head and waist by mandibles and attacking appendages by mandibles $(0.97, \mathrm{p} \leq 0.05)$, opening of mandibles and attacks using poison $(-0.93, \mathrm{p} \leq 0.05)$, attacking the head and waist by mandibles and an attack using poison $(0.99, \mathrm{p} \leq 0.05)$, attacking appendages and attacks using poison $(0.95, \mathrm{p} \leq 0.05)$. High level of correlation was obtained between the number of workers killed and: a) an attack of the head and waist by mandibles $(0.99, \mathrm{p} \leq 0.05), \mathrm{b})$ an attack of appendages by mandibles $(0.96, \mathrm{p} \leq 0.05)$ and $\mathrm{c})$ an attack using poison $(0.99, \mathrm{p} \leq 0.05)$. The number of contacts positively correlated with opening of the mandibles $(0.91, \mathrm{p} \leq 0.05)$, and negatively correlated with: a) attack of appendages by mandibles $(-0.96, \mathrm{p} \leq 0.05)$, b) attack by mandibles $(-0.99, \mathrm{p} \leq 0.05)$, c) attack with poison $(-0.99, \mathrm{p} \leq 0.05)$.

If an attack occurs, regardless of its character at least one of the participants was killed. The severity of the conflicts between workers of L. neglectus from different colonies, as well as the mortality rate, directly depends on the number of participants.

The opposite results were obtained in the secondary area of L. neglectus (Rostov-onDon, forest belt). While no reliable correlations were found, with an increasing of the number of experiment's participants, the number of contacts between workers increased 4-6 times, however any kinds of aggression or threatening poses were not recorded (table 2). That is, workers of $L$. neglectus from different colonies in the native range demonstrate aggressiveness towards each other, but in the secondary one they are tolerant to each other. 


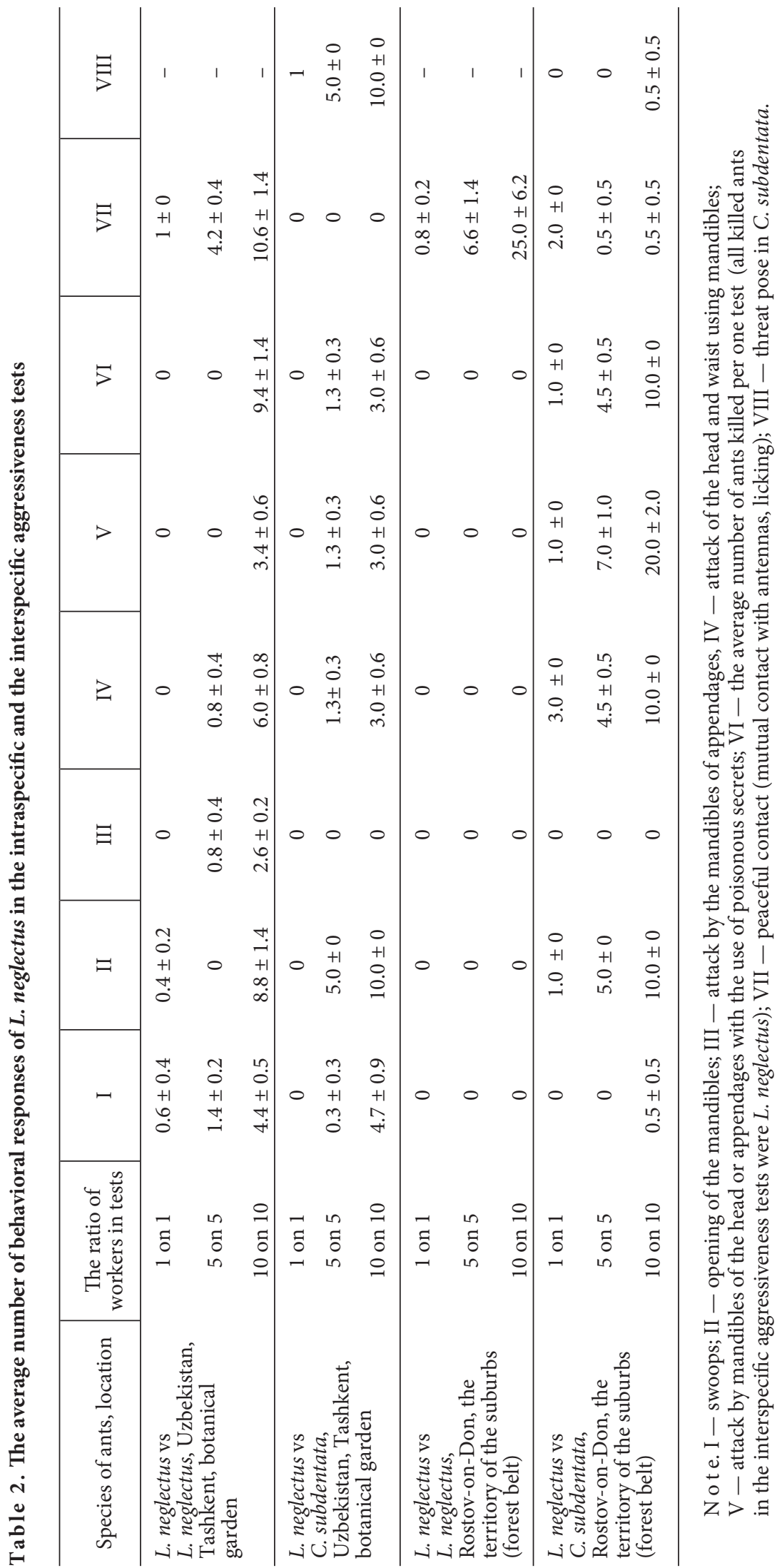


In relation to $C$. subdentata, workers of $L$. neglectus avoided contact both in the native and secondary areas, the number of contacts was 10-20 times less than those in the intraspecific tests of L. neglectus ( $\mathrm{p} \leq 0.05$ ).

Interspecific tests in the native range (Tashkent, Botanical Garden) showed trends similar to intraspecific ones, but less pronounced. In the tests five to five, attacks by C. subdentata resulted by an attack using mandibles (0.66) or poison (0.66). In tests of 10 to 10 , the attacks by C. subdentata also resulted in using poison (0.65), using mandibles (0.65) and the death of L. neglectus workers (0.65).

In the secondary area (Rostov-on-Don, forest belt), the five to five and 10 to10 interspecific tests together showed that opening the mandibles by C. subdentata resulted in attacks: with mandibles (0.96), formic acid ( $L$. neglectus response in the case of C. subdentata attack), or repellent (in the attack of C. subdentata on L. neglectus, when this species initiated attack) (0.97), and the death of L. neglectus workers (0.99).

Thus, during intraspecific contacts of $L$. neglectus workers in the native area, the opening of the mandibles is more likely a threatening pose, most often not ending with an attack. In the interspecific fights both in the native and secondary areas, on contrary, opening of the mandibles in L. neglectus preceded an attack in response against the attacker (C. subdentata).

\section{Discussion}

Main characteristics of L. neglectus in the native range. Comparison with traits of other invasive species in native ranges

Many invasive ant species share similar biological traits in their secondary areas. For example, they form there supercolonies, have a high density of workers in the foraging area, are tolerant to workers of their own species from other nests and aggressive towards other species of ants, are polygynous. The latter feature is often characteristic to them in the native range as well, what, in fact, in many respects determines the ability of wide expansion of invasive species in colonized (secondary) areas.

At the same time, colonies of many invasive species in native areas are monocalic and workers from different colonies are aggressive towards each other. For example, though M. rubra occasionally forms large polycalic colonies within the native range, its colonies in the Palaearctic are overwhelmingly monocalic and include from several hundreds to 5-10 thousand workers that are aggressive towards workers of the same species from other nests (Radchenko \& Elmes, 2010; Radchenko, 2016). This species was introduced to North America more than a hundred years ago and spread widely in the eastern regions of the USA and Canada, and in some places it forms supercolonies numbering hundreds of thousands and even millions of workers (Radchenko \& Elmes, 2010; Wetterer \& Radchenko, 2011; Chen \& Adams, 2018). A similar pattern was observed for L. humile, whose colonies are monocalic and workers are aggressive towards each other in the native range, in contrast to those in the secondary one (Holway et al., 1998; Suarez et al., 1999; Tsutsui \& Case, 2001; Wetterer \& Wetterer, 2006; Felden et al., 2019). At the same time, the invasive species Paratrechina longicornis (Latreille, 1802) exhibits intraspecific aggressiveness both in the native and secondary ranges (Lim et al., 2003; Wetterer, 2008).

Colonies of $L$. neglectus in the native range are also polygynous, but monocalic and workers are aggressive towards individuals from other colonies of the same species. But at the same time the number of queens in one colony in the native range is significantly lower than in the secondary areas, where the total number of queens in large supercolonies can reach hundreds of thousands (Espadaler et al., 2004).

The colonies size of $L$. neglectus in Uzbekistan is also smaller than that in the secondary range. Other ant species can inhabit its foraging areas, whereas the diversity of local species abruptly decreased in the territories of invasion of L. neglectus (Van Loon et al., 1990; Nagy et al., 2009). At that, large colonies of this species can monopolize separate trees with aphid 
colonies and baits, completely crowding out local species (Paris \& Espadaler, 2012; Gippet et al., 2018). The capacity of honeydew collected by L. neglectus can be several times higher than that of native ants (Paris \& Espadaler, 2009).

\section{Hierarchy}

L. neglectus not only loses fights with C. subdentata in the tests, but also avoids contact with that species. On the contrary, L. neglectus is highly aggressive towards local species of ants in the secondary areas (Cremer et al., 2006). That is behavior of L. neglectus is different in the native and secondary areas. It should be noted that aggressiveness of ants directly depends on the size of the colonies and the dynamic density of workers on the foraging area (Zakharov, 1991).

Nuptial flight and the establishing of new colonies in L. neglectus

A characteristic feature of $L$. neglectus is the existence of nuptial flight in the native range and exclusive intra-nest mating in the secondary areas. The ability of establishing colonies both independently by fertilized gynes and by budding has been confirmed in laboratories experiments (Espadaler \& Rey, 2001), but the low nutrient content in the body of females in the secondary areas indicates that the latter option seems more preferable. Our data also indicate the possibility of independent founding of new colonies after the nuptial flight in L. neglectus in the native range. The existence of at least irregular nuptial flights is also indicated by findings of winged females in spider webs in Kyrgyzstan (Seifert, 2000). Thus, when adapting to new conditions in the invasive range, L. neglectus lost its nuptial flights, moving to a less "costly" and safer way of establishing new nests by budding.

\section{The primacy of the area}

In Kyrgyzstan L. neglectus was found in large quantities in almost 20 localities at altitudes ranging from 600 to $1600 \mathrm{~m}$, but exclusively in anthropogenic habitats (cities, towns), where it possesses all the traits of an invasive species (Schultz \& Seifert, 2005; Schultz et al., 2006; Borowiec et al., 2009). In countries neighboring Uzbekistan and Kyrgyzstan, e. g. in Kazakhstan, Tajikistan, and western China this species was not found (Schultz \& Seifert, 2005; Guénard \& Dunn, 2012). That is, it is possible to assume that Kyrgyzstan the most likely is a part of the invasive range of L. neglectus.

As mentioned above, so far the place of origin of $L$. neglectus was assumed to be in the Asia Minor or the "Black Sea area". Seifert (2000) based this assumption on the morphological similarity of L. neglectus and Minor Asian species L. turcicus, although he did not take into account the similarity of this species with L. psammophilus Seifert, 1992. Probably, in the future, molecular genetic studies will be able to shed light on the relations of $L$. neglectus with other species of the genus.

Based on the complex of genetic, biochemical and ethological studies, it was shown that various European populations of L. neglectus formed as a result of several independent introductions, but the place of its origin remains unclear. Moreover, three populations from Edirne (Turkey) are considered the youngest, and one of them is unrelated to the other two (Ugelvig et al., 2008).

In our opinion, the real evidence of the nativity of the range of invasive ant species can be its inhabiting in the natural biotopes, as well as the biological and behavioral features that differ from those in the secondary (invasive) areas. To date, L. neglectus has been found in natural habitats only twice: in a steppe location in Turkey (Seifert, 2000) and in the Kanak gulch in Crimea, but in the latter case it is also associated with anthropogenic influence (Stukalyuk \& Radchenko, 2018).

Thus, natural populations of L. neglectus were found only in Uzbekistan, where this species is widespread and does not have biological features inherent to invasive species. In particular, the level of polygyny in its colonies is much lower than in the secondary areas, 
there is no polycaly and it does not form supercolonies, workers are aggressive towards those from other colonies, this species does not dominate in the multi-species associations of ants, and, finally, it has a true nuptial flight.

All mentioned above allows us to assume with great certainty that the native range of L. neglectus is located in the Central Asia, particularly, in Uzbekistan. It could easily penetrate many settlements in Uzbekistan from its natural habitats, and also has been introduced into the cities of neighboring Kyrgyzstan. But the question remains open: in what way did L. neglectus reach the Transcaucasia, Asia Minor and Europe?

The earliest occurrences of L. neglectus in the secondary range date back to the 1970s: it was found in Budapest in 1973 (Van Loon et al., 1990), in Pitsunda on the Black Sea coast of Georgia in 1974 (Seifert, 2000), in Alushta in Crimea in 1978 (Stukalyuk \& Radchenko, 2018), although it could have been introduced to these locations even earlier. It has to be emphasized that L. neglectus was formally described only in 1990 and before that time various authors might determined it as L. alienus Foerster, 1850 (Van Loon et al., 1990). Seifert (1992) revised the subgenus Lasius s. str. and not only divided L. alienus into several species, but also considered the name L. neglectus the junior synonym of L. turcicus. Subsequently, he resurrected the name L. neglectus from synonymy (Seifert, 1996), and only since the late 1990s to the present, there has been an increased interest of researchers in a comprehensive study of this invasive species. It should be also noticed that in Europe, where L. turcicus is absent, L. neglectus may be confused with the widespread and morphologically similar L. psammophilus, especially if studied material originate from museum's collections and exact habitat data are absent.

To date, there is no reliable information on the occurring of L. neglectus in Turkmenistan, but it should be noted that during last 30-40 years myrmecological studies in this country have not been carried out. Dlussky et al. (1990) recorded L. alienus for Turkmenistan, noting that this species is found in Central Asia in the mountains and parks of large cities, including Tashkent. In Turkmenistan, it was found in Ashgabat, Geok-Tepe, Kara-Tepe and in Western Kopetdag. But, based on current knowledge, L. alienus is absent in Turkmenistan, and it can be assumed that mentioned authors dealt with L. neglectus, at least in cities. Indirectly, this can be confirmed by the findings of L. neglectus in northern Iran - the territory adjacent to Kopetdag (Paknia et al., 2008; Ghahari et al., 2009).

Further invasion to the west could have passed through Transcaucasia and / or Asia Minor, where L. neglectus was found in the 1980s (Seifert, 2000). However, the distribution paths of this species could be very diverse and various European populations were formed by the several "waves" of invasion (Ugelvig et al., 2008). One may also assume a direct path of expansion of L. neglectus to Europe from the native range (Uzbekistan) at least in the early 1970s or even earlier, for example, with plant seedlings exchange between the botanical gardens of the former socialist countries, not to mention about exchange of goods within the former USSR (deliveries to Georgia or the Crimea). The idea about introduction of L. neglectus to Budapest directly from Asia Minor (Espadaler et al., 2007) contradicts the known data of the time of the earliest findings of this species in these areas: in 1973 in Budapest, and in the late 1980s in Turkey. It should be noted that the Crimean population of L. neglectus may be even older than that of Budapest, since in Crimea some its supercolonies have already begun to degrade (Stukalyuk \& Radchenko, 2018) like some supercolonies in other places of Europe (Tartally et al., 2016). That is, one cannot completely rule out the introduction of L. neglectus to Budapest from the Crimea.

\section{Conclusion}

The initial condition for the successful expansion of L. neglectus is its polygyny in the native range. Other characteristics of this species (multipolygyny, aggressiveness toward other species, fertilization inside nests, tolerance to conspecific workers etc.) were formed 
in this species in the secondary area (invasion zone). Due to the large number of workers in colonies in the invasion range, some other biological characters are also increased, such as trophobiosis with aphids and aggressiveness toward other ant species. Since loss of the nuptial flight, the species spreading has become passive, depending mainly on human activity. At the same time, the "invasive properties" of L. neglectus could start to form even in the cities of Uzbekistan.

Be that as it may, our results and the conclusion that Uzbekistan is the native range of L. neglectus do not contradict all available data on the distribution and biological traits of this species.

\section{References}

Borowiec, M., Borowiec, L., Csősz, S., Radchenko, A. 2009. Ants collected during 2006 Polish expedition to Kyrgyzstan (Hymenoptera: Formicidae). Genus, 20 (2), 367-379.

Buckham-Bonnett, P., Robinson, E. J. H. 2018. Non-native Species Rapid Risk Assessment: Rapid Risk Assessment of L. neglectus (Invasive Garden Ant). White Rose Research, York, 1-15.

Chen, W., Adams, E. S. 2018. The Distribution and Habitat Affinities of the Invasive Ant Myrmica rubra (Hymenoptera: Formicidae) in Southern New England. Environmental Entomology, 20 (10), 1-8.

Cremer, S., Ugelvig, L. V., Lommen, S. T. E., Petersen, K. S., Pedersen, J. S. 2006. Attack of the invasive garden ant: aggression behaviour of L. neglectus (Hymenoptera: Formicidae) against native Lasius species in Spain. Myrmecologische Nachrichten, 9, 13-19.

Cremer, S., Ugelvig, L. V., Drijhhout, F. P., Schlick-Steiner, B. C., Steiner, F. M., Seifert, B., Hughes, D. P., Schulz, A., Petersen, K. S., Konrad, H., Stauffer, C., Kiran, K., Espadaler, X., d'Ettorre, P., Aktaç, N., Eilenberg, J., Jones, G. R., Nash, D. R., Pedersen, J. S., Boomsma, J. J. 2008. The evolution of invasiveness in garden ants. PLoS One, 3, e3838.

Czechowski, W., Radchenko, A., Czechowska, W., Vepsäläinen, K. 2012. The Ants of Poland with Reference to the Myrmecofauna of Europe. Natura Optima Dux Foundation, Warszawa, 1-496.

Dlussky, G. M., Soyunov, O. S., Zabelin, S. I. 1990. The ants of Turkmenistan. Ylym, Ashkhabad, 1-275 [In Russian].

Espadaler, X., Rey, S. 2001. Biological constraints and colony founding in the polygynous invasive ant L. neglectus (Hymenoptera, Formicidae). Insectes Sociaux, 48, 159-164.

Espadaler, X., Rey, S., Bernal, V. 2004. Queen number in a supercolony of the invasive garden ant, L. neglectus. Insectes Sociaux, 51, 232-238.

Espadaler, X., Tartally, A., Schultz, R., Seifert B., Nagy, C. 2007. Regional Trends and Preliminary Results on the Local Expansion Rate in the Invasive Garden Ant, L. neglectus (Hymenoptera, Formicidae). Insectes Sociaux, 54, 293-301.

Felden, A., Paris, C., Chapple, D. G., Suarez, A. V., Tsutsui, N. D., Lester, P. J., Gruber, M. A. M. 2019. Native and introduced Argentine ant populations are characterized by distinct transcriptomic signatures associated with behaviour and immunity. NeoBiota, 49, 105-126.

Ghahari, H., Collingwood, C. A., Tabari, M., Ostovan, H. 2009. Faunistic notes of Formicidae (Insecta: Hymenoptera) of rice fields and surrounding grasslands in northern Iran. Munis Entomology and Zoology Journal, 4 (1), 184-189.

Gippet, J. M. W., Piola, F., Rouifed, S., Viricel, M.-R., Puijalon, S., Douady, C. J., Kaufmann, B. 2018. Multiple invasions in urbanized landscapes: interactions between the invasive garden ant L. neglectus and Japanese knotweeds (Fallopia spp.). Arthropod-Plant Interactions, doi: 10.1007/s11829-017-9589-2.

Giraud, T., Pedersen, J. S., Keller, L. 2002. Evolution of supercolonies: the Argentine ants of southern Europe. Proceedings of the National Academy of Sciences, 99 (9), 6075-6079.

Guénard, B., Dunn, R. R. 2012. A checklist of the ants of China. Zootaxa, 3558, 1-77.

Holway, D. A., Suarez, A. V., Case, T. J. 1998. Loss of intraspecific aggression in the success of a widespread invasive social insect. Science, 93, 949-952.

Holway, D. A., Lanch, L., Suarez, A. V., Tsutsui, N. D., Case, T. J. 2002. The causes and consequences of ant invasions. Annual Review of Ecology \& Systematics, 33, 181-233.

Le Moli, F., Parmigiani, S. 1981. Laboratory and field observations of attack by the red wood ant Formica lugubris Zett. on Formica cunicularia Latr. (Hymenoptera: Formicidae). Aggressive Behavior, 7, 341-350.

Lim, S. P., Chong, A. S. C., Lee, C. Y. 2003. Nestmate recognition and intercolonial aggression in the crazy ant, Paratrechina longicornis (Hymenoptera: Formicidae). Sociobiology, 41, 295-305.

Mayr, G. 1877. Formicidae. In: Fedchenko, A. P. Travels in Turkestan. Izvestia Imperatorskogo Obshchestva Lyubitelei Estestvoznania, Antropologii i Etnografi pri Imperatorskom Moskovskom Universitete, Moskva, 1-20 [In Russian].

Nagy, C., Tartally, A., Vilisics, F., Merkl, O., Szita, E., Szel, G., Podlussany A., Redei D., Csosz, S., Posgai, G., Orosz, A., Szovenui, G., Marko, B. 2009. Effects of the invasive garden ant, L. neglectus van Loon, Booms- 
ma and Andrasfalvy, 1990 (Hymenoptera: Formicidae), on arthropod assemblages: pattern analyses in the type supercolony. Myrmecological News, 12, 171-181.

Paknia, O., Radchenko, A., Alipanah, H., Pfeiffer, M. 2008. A preliminary checklist of the ants (Hymenoptera: Formicidae) of Iran. Myrmecological News, 11, 151-159.

Paris, C., Espadaler, X. 2009. Honeydew collection by the invasive garden ant L. neglectus versus the native ant L. grandis. Arthropod-Plant Interactions, 3, 75-85.

Paris, C., Espadaler, X. 2012. Foraging Activity of Native Ants on Trees in Forest Fragments Colonized by the Invasive Ant L. neglectus. Psyche, 1-9.

Radchenko, A. G. 2016. The ants (Hymenoptera: Formicidae) of Ukraine. Schmalhausen Institute of Zoology, Kiev, 1-495 [In Russian].

Radchenko, A. G., Bazhenova, T. N., Simutnik, E. I. 2012. Findings of Earlier Unrecorded and Little Known Species and a Genus of Ants (Hymenoptera: Formicidae) in the Fauna of Ukraine. Ukraïnska Entomofaunistika, 3 (2), 1-9 [In Russian].

Radchenko, A., Elmes, G. W. 2010. Myrmica ants (Hymenoptera, Formicidae) of the Old World. Natura Optima Dux Foundation, Warszawa, 1-789.

Rey, S., Espadaler, X. 2004. Area-wide management of the invasive garden ant L. neglectus (Hymenoptera: Formicidae) in Northeast Spain. Journal of Agricultural Urban Entomology, 21(2), 99-112.

Schulz, R., Radchenko, A., Seifert, B. 2006. A critical checklist of the ants of Kyrgyzstan (Hymenoptera: Formicidae). Myrmecologische Nachrichten, 8, 201-208.

Schultz, R., Seifert, B. 2005. L. neglectus (Hymenoptera: Formicidae) - a widely distributed tramp species in Central Asia. Myrmecologische Nachrichten, 7, 47-50.

Seifert, B. 1992. A taxonomic revision of the Palaearctic members of the ant subgenus Lasius s. str. Abhandlungen und Berichte des Naturkundemuseums Görlitz, 66, 1-67.

Seifert, B. 1996. Ameisen: beobachten, bestimmen. Naturbuch Verlag, Augsburg, 1-351 [In German].

Seifert, B. 2000. Rapid range expansion in L. neglectus (Hymenoptera, Formicidae) - an Asian invader swamps Europe. Mitteilungenaus dem Museum für Naturkinde in Berlin, Deutsche Entomologische Zeitschrift, 47, 173-179.

Stukalyuk, S. V. 2015. Crematogaster subdentata Mayr, 1877, a potentially invasive species of ant (Hymenoptera, Formicidae) new to the fauna of Crimea. Entomological Review, 95 (8), 1021-1035.

Stukalyuk, S. V. 2017.The Beginning of the Invasion of L. neglectus (Hymenoptera, Formicidae) in Kiev (Ukraine). Entomological Review, 97 (8), 1063-1065.

Stukalyuk, S. V., Netsvetov, M. V. 2018. The effect of invasion of Crematogaster subdentata Mayr on the structure of ant assemblages (Hymenoptera, Formicidae) in Crimea. Zhurnal obshcheı biologii, 79 (4), 294-317 [In Russian].

Stukalyuk, S. V., Radchenko, A. G. 2018. L. neglectus Van Loon et al. (Hymenoptera, Formicidae), an Invasive Ant Species in Crimea. Entomological Review, 98 (6), 690-701.

Suarez, A. V., Tsutsui, N. D., Holway, D. A., Case, T. J. 1999. Behavioral and genetic differentiation between native and introduced populations of the Argentine ant. Biological Invasions, 1 (1), 43-53.

Suarez, A. V., McGlynn, T. P., Tsutsui, N. D. 2010. Biogeographic and taxonomic patterns of introduced ants. In: Lach L., Parr C. L., Abbott K. L., eds. Ant Ecology. Oxford University Press, Oxford, 233-244.

Tartally, A., Antonova, V., Espadaler, X., Csösz, S., Czechowski, W. 2016. Collapse of the Invasive Garden Ant, L. neglectus, Populations in Four European Countries. Biological Invasions, 18 (11), 3127-3131.

Tsutsui, N. D., Case, T. J. 2001. Population genetics and colony structure in the Argentine ant (Linepithema humile) in its native and introduced ranges. Evolution, 55, 976-985.

Tsutsui, N. D., Suarez, A. V. 2003. The Colony Structure and Population Biology of Invasive Ants. Conservation Biology, 17 (1), 48-58.

Ugelvig, L. V., Drijfhout, F. P., Kronauer, D. J. C., Boomsma, J. J., Pedersen, J. S., Cremer, S. 2008. The introduction history of invasive garden ants in Europe: integrating genetic, chemical and behavioural approaches. BMC Biology, 6, 11.

Van Loon, A. J., Boomsma, J. J., Andrásfalvy, A. 1990. A new polygynous Lasius species (Hymenoptera: Formicidae) from Central Europe. Insectes Sociaux, 37, 348-362.

Wetterer, J. K. 2008. Worldwide spread of the longhorn crazy ant, Paratrechina longicornis (Hymenoptera: Formicidae). Myrmecological News, 11, 137-149.

Wetterer, J. K., Radchenko, A. G. 2011. Worldwide spread of the ruby ant, Myrmica rubra (Hymenoptera: Formicidae). Myrmecological News, 14, 87-96.

Wetterer, J. K., Wetterer, A. L. 2006. A disjunct Argentine ant metacolony in Macaronesia and southwestern Europe. Biological Invasions, 8, 1123-1129.

Wild, A. L. 2004. Taxonomy and distribution of the Argentine ant, Linepithema humile (Hymenoptera: Formicidae). Annales of Entomological Society of America, 97 (6), 1204-1215.

Zakharov, A. A. 1991. Organization of ant communities. Nauka, Moscow, 1-276 [In Russian].

Received 3 February 2020

Accepted 25 February 2020 